\title{
Fitoösztrogének a menopauza terápiájában
}

\author{
Remport Júlia TDK-hallgató - Blázovics Anna dr.
}

\author{
Semmelweis Egyetem, Gyógyszerész-tudományi Kar, Farmakognóziai Intézet, Budapest
}

\begin{abstract}
A korábbi évszázadokban a társadalmi és gazdasági körülmények, az orvostudomány hiányosságai, a járványok és a háborúk miatt rövid volt a várható élettartam, így a nók többsége meg sem érte a változókort. Napjainkban a fejlett országokban az emberek átlagosan 75-80 éves korukig élnek, az átlagéletkor kitolódásával nő a menopauzában érintettek, illetve a menopauzában töltött évek száma, mára már a nók életük harmadát menopauzában töltik. A kellemetlen tünetek kezelésének egyetlen hatékony módját évszázadokon át a gyógynövények alkalmazása jelentette, amely ismeret szájhagyomány útján terjedt. A XX. században a szintetikus gyógyszergyártás kialakulásával és a hormonpótló kezelés bevezetésével ez a terápiás forma háttérbe szorult. A média hatására a XX. században kialakult az a társadalmi igény a nők körében, hogy minél tovább megőrizzék szépségüket és fiatalságukat. A hormonpótló terápia nagy népszerűségnek örvendett, mert a nők átmenetileg megszabadultak életminőségüket rontó tüneteiktől, viszont évekkel később kiderült, hogy a hormonpótlás komoly veszélyekkel járhat. A gyógynövényes terápiáknak határozott előnye a hormonpótló kezelésben használt szintetikumokkal szemben a kedvezőbb mellékhatásprofil. A nők ezért ismét szívesen fordulnak a bevált természetes gyógymódokhoz. Egyre növekszik az érdeklődés a gyógynövénytartalmú készítmények iránt. A fitoösztrogének hatásának tanulmányozása mára már a kutatások aktív területévé vált. Az állatokon és embereken végzett vizsgálatok eredményei azonban ellentmondásosak, egyes források szerint a fitoösztrogének hatékonynak és biztonságosnak bizonyulnak, más szerzók szerint hatástalanok menopauzában vagy kifejezetten veszélyesek, nem ajánlhatók mindenkinek. A nők testi, mentális egészsége és biztonsága érdekében fontos ezzel a kérdéssel foglalkozni, alkalmazásuk előtt ezért szükséges felmérni az előnyöket és a rizikót.
\end{abstract}

Orv Hetil. 2017; 158(32): 1243-1251.

Kulcsszavak: menopauza, hormonpótló kezelés, fitoösztrogének, izoflavonoidok, szója

\section{Phytoestrogens in the treatment of menopause}

In previous centuries many women did not even live until their menopause years due to poor economic conditions, deficiencies of medicine, epidemics and wars. Nowadays in the developed countries, people live until they are $75-80$ years old, and with the expansion of average age, the number of people affected by menopause and the years spent in that state increase. Nowadays women spend one third of their lives in the menopausal stage. The only effective way to treat unpleasant symptoms for centuries was with the use of herbs, and the knowledge about them spread through oral tradition. In the 20th century, this therapeutic form was pushed into the background by the development of synthetic drug production and the introduction of hormone replacement therapy. Thanks to the influence of media in the 20th century, women began to have the social need for preserving their beauty and youth for as long as they could. Hormone replacement therapy enjoyed great popularity because women were temporarily relieved of their life quality-impairing menopausal symptoms, but years later it turned out that hormone replacement therapy could pose serious risks. A distinct advantage of herbal therapy is the more advantageous side-effect-profile opposite the used synthetics in hormone replacement therapy. Women are therefore happy to turn to valuable and well-tried natural therapies, which have been used for thousands of years. There is growing interest in herbal remedies. Studying the effects of phytoestrogens has now become an active area for research. However, the results of studies in animals and humans are controversial, some sources suggest that phytoestrogens are effective and safe, other authors claim that they are ineffective in menopause or they have particularly dangerous properties, and cannot be recommended to everyone. It is important to address this issue for the sake of health, mental health and safety of women, and so it is necessary to assess the benefits and the risks before applying them.

Keywords: menopause, hormone replacement therapy, phytoestrogens, isoflavonoids, Glycine max

Remport J, Blázovics A. [Phytoestrogens in the treatment of menopause]. Orv Hetil. 2017; 158(32): 1243-1251.

(Beérkezett: 2017. május 10.; elfogadva: 2017. június 19.) 


\section{Rövidítések}

AICR $=($ American Institute for Cancer Research $)$ Amerikai Rákkutató Szövetség; DNS = dezoxiribonukleinsav; ER $\alpha=$ (estrogen receptor $\alpha$ ) ösztrogénreceptor- $\alpha$; ER $\beta=($ estrogen receptor $\beta)$ ösztrogénreceptor $-\beta ;$ FMRl $=($ fragile $X$ mental retardation 1$)$ fragilis $\mathrm{X}$ mentális retardáció- $\mathrm{l} ; \mathrm{HDL}=($ high density lipoprotein) nagy sűrűségú lipoprotein; HIF-1 = hypoxia indukálta faktor-1; HPK = hormonpótló kezelés; HUVEC = (human umbilical vein endothelial cells) humán köldökvénaendothelsejtek; $\mathrm{LDL}=($ low density lipoprotein $)$ alacsony súrüségú lipoprotein; MMP-2 = mátrixmetalloproteáz-2; NOS = nitrogén-monoxid-szintáz; PDGF $=$ (platelet-derived growth factor) vérlemezke-eredetű növekedési faktor; SERM = (selective estrogen receptor modulator) szelektív ösztrogénreceptormodulátor; $\mathrm{uPa}=$ urokináz plazminogén aktivátor; VEGF = (vascular endothelial growth factor) vascularis endothelialis növekedési faktor; WHO $=$ (World Health Organization) Egészségügyi Világszervezet

\section{A menopauza és tünetei}

A természetes menopauza hátterében nem áll patológiai tényező. Amenorrhoea kóros menopauza révén is kialakulhat, aminek kóroki tényezői között szerepelnek a kemoterápiás és a sugárterápiás kezelések, a belső női ivarszervek mútéti eltávolítása és a korai menopauza, ami az Egészségügyi Világszervezet (WHO) definíciója szerint 40 éves kor előtt alakul ki [1].

A menopauza nemcsak testi tünetekben manifesztálódhat, a hormonváltozások befolyással lehetnek a nők hangulatára, szociális és szexuális életére is. A különféle lelki változások hangulatingadozásokban, általános kimerültségben, szorongásban, ingerlékenységben jelentkeznek [2]. Vizsgálatok összefüggésbe hozták a depreszsziót és a menopauza kialakulásának időpontját, amelyek szerint minél korábban csökken az ösztrogénszint a szervezetben, annál nagyobb mértékben nő a depresszió kialakulásának kockázata [3].

A később kialakuló menopauzát összefüggésbe hozták a magasabb várható élettartammal, csökkent mortalitási adatokkal és cardiovascularis betegségek (atherosclerosis, angina) incidenciájának csökkenésével. Kedvező hatásai mellett azonban a rákos megbetegedések (emló- és petefészekrák) kockázatát növeli [4]. A változókor első tünetei megjelenésének idejét számos faktor befolyásolja, köztük az örökletes tényezők és az életmód.

Vizsgálatok igazolták a genetika szerepét a klimax folyamatában. Snieder és mtsai egy- és kétpetéjú ikreken végzett vizsgálatai szerint mind a korai, mind a késői menopauzát befolyásolják genetikai faktorok. A klimax kialakulásának idejében megjelenő, egyének közötti különbségek 63\%-át genetikai faktorok okozzák. A klimaktérium kialakulásában a petefészek mellett az agytevékenység is kulcsfontosságú, mindkét szerv irányítófunkciója nagymértékben genetikai kontroll alatt áll. Eredményeik szerint azonban nincs összefüggés a menarche kialakulásának ideje és a menopauza lefolyása között [5].
Szoros összefüggést találtak az anyák és lányaik klimaxa között, ami alapján az anya változókorának kezdete és lefolyása jelző értékú. Családfaelemzések kimutatták, hogy a korai menopauza és az idő előtti petefészek-elégtelenség öröklődik, az FMRl gén módosulásának (trinukleotid-ismétlódés hosszában bekövetkező változás) következményeként [6].

A dohányzás a korai menopauza kialakulásának kockázatát növelheti. Egy ausztrál tanulmány szignifikáns öszszefüggést állapított meg a dohányzás és a korai menopauza között. Dohányzó nőknél 43\%-kal nagyobb valószínúséggel alakult ki a menopauza 50 éves kor előtt. Ez az állapot rontja az életkilátásokat és idő előtti mortalitást eredményez. Feltevések szerint a dohányzás toxikus hatása irreverzibilis a petefészek funkciójára, ezért vizsgáltak dohányzásról leszokott nóket is. A nem dohányzó nőkhöz képest nincs fokozott kockázat a korai menopauza szempontjából, a leszokás ideje azonban fontos tényező. Akik később teszik le a cigarettát, azoknál nagyobb valószínúséggel alakult ki korábban a menopauza. A dohányzás mértéke is lényeges faktor. A vizsgálat szerint naponta 20 szálnál többet szívó nők menstruációs ciklusa hamarabb szûnt meg a többi (nem dohányzó, kevesebbet dohányzó) csoporthoz képest, átlagosan 46 éves korban [7].

A vegetáriánusok a húst fogyasztókkal összehasonlítva szignifikánsan korábban estek túl a klimaxon, ez a jelenség független attól, hogy az illető 20 éves kora előtt vagy 20-40 éves kora között tért át a húsmentes életmódra. A fizikai aktivitás későbbi klimaktériumot eredményez, a rendszeresen sportoló (3,2 óra/hét) nők esetében szignifikánsan később kezdődött el a klimax, mint azoknál a nőknél, akik a testmozgást elhanyagolták [8].

\section{Hormonok és hormonpótlás}

Az ösztrogén azonos hatású, hasonló szerkezetű vegyületek gyújtőneve, a 17ß-ösztradiol, az ösztron és az ösztriol alkotja. A női nemi hormonok közös jellemzője a szteroidvázon kívül az aromás $\mathrm{A}$ gyưrú hármas szénatomján található hidroxilcsoport és a $\mathrm{D}$ gyứrü $\mathrm{C}_{17}$-es pozíciójában egy hidroxil- vagy egy oxocsoport jelenléte.

$\mathrm{Az}$ ösztrogénreceptor két típusát izolálták, az ösztrogénreceptor- $\alpha-t(E R \alpha)$ és az ösztrogénreceptor- $\beta$-t $(\operatorname{ER} \beta)$. A sejtekben homo- és heterodimerként is előfordulhatnak [9]. Bizonyos szövetek között eloszlásukban különbséget figyeltek meg. Az ER a túlnyomó expressziója a méhben, hüvelyben, petefészekben, emlőben, hypothalamusban történik, ER $\beta$ esetében pedig a petefészekben, csontban, tüdőben és az agyban. A kötődéshez szükségesek bizonyos szerkezeti tulajdonságok, ilyenek például a fenolos gyưrú jelenléte, ami H-hidat tud képezni. $\mathrm{A} \mathrm{C}_{17}$-helyzetben elengedhetetlen olyan funkciós csoport jelenléte, amely H-kötést tud kialakítani. Szerkezeti feltétel továbbá az oxigéntartalmú csoportok távolsága molekulán belül $\left(\mathrm{C}_{3}-\mathrm{C}_{17}\right)$ és a hidrofób tulajdonság. 
Az ER $\alpha$ és az ERß egyaránt sejtmagreceptorok, az ösztrogének mindkét típushoz kötődnek, a receptorok sejtmagba vándorolva az ott lévő DNS-hez kötődve gének átírását befolyásolják, például nitrogén-monoxidszintáz (NOS), prosztaciklinszintáz fehérjék génjeit [10].

A női nemi hormonok reproduktív rendszeren kívüli hatásai is ismertek. Az ösztrogénnek fontos szerepe van a lipidhomeosztázis fenntartásában. Regulálja a zsírsavak $\beta$-oxidációját a mitokondriumokban és a peroxiszómákban. Szabályozza emellett még a koleszterin szintézisét és felvételét is. A nők magasabb ösztrogénszintjük miatt kevésbé vannak kitéve a dyslipidaemiával összefüggő betegségeknek. Menopauza után azonban, a férfiakhoz hasonlóan, náluk is romlik a lipidprofil, az atherosclerosis és az azzal összefüggésbe hozható egyéb betegségek kockázata megnő [11]. Az ösztrogénhiány következménye a posztmenopauzás osteoporosis, amelynek során csökken a csontok szilárdsága, rugalmassága, ezzel öszszefüggésben növekszik a törések kockázata. A csontállomány menopauza után évi 1-2\%-kal csökken, a 80. életév betöltésekor a változókor előtti csontállomány fele marad meg csupán [12]. Nőstény egereken végzett kísérletben bizonyították, hogy az ösztradiol ER $\alpha$-n keresztül és a Fas/Fas ligandrendszer aktivációjával a csontszöveteket lebontó osteoclastok apoptózisát indukálja, ezáltal oszteoprotektív hatást igazoltak [13].

A hormonpótló kezelés (HPK) hatékonyan tudja csökkenteni a változókor kellemetlen tüneteit, azonban nem veszélytelen kezelés, mert komoly rizikóval, mellékhatásokkal járhat.

Az ösztrogének só- és vízretenciót fokozó hatásukkal növelik az ödémahajlamot, gyakori mellékhatásuk még a hányinger, hányás, puffadás, fejfájás, szorongás, depreszszió, emlőfeszülés. A HPK-k kapcsán tumorkeltő tulajdonságot állapítottak meg az emlőben és az endometriumban, illetve a már kialakult tumorok méretének növekedését tapasztalták, ami a sejtproliferációt fokozó hatással magyarázható. Az ösztrogének serkentik a véralvadási faktorok és a fibrinogén szintézisét, emiatt fokozódik a véralvadásra való hajlam, a vénás thromboembolia kialakulásának rizikója [14].

A HPK abszolút kontraindikációi közé tartozik a korábban elszenvedett vénás (mélyvénás trombózis, tüdőembólia) vagy artériás thromboembolia (angina, myocardialis infarctus), emlőrák (gyanú esetén is), nem diagnosztizált vaginális vérzés, súlyos akut májbetegség, endometriumcarcinoma. Relatív kontraindikáció a fejfájás, kezeletlen magas vérnyomás, családon belül előforduló emlő- vagy petefészekrák, fennálló epebetegség [15].

\section{Fitoösztrogének}

A fitoösztrogének olyan növényi eredetű vegyületek, amelyek a szervezet ösztrogénreceptoraihoz képesek kötődni, és azokon hatást váltanak ki. Hatáserősségük je- lentősen kisebb az endogén női nemi hormonokhoz képest, azonban menopauzában, amikor csökken a szervezet ösztrogénszintje, jótékony hatásaikat ki lehet használni.

Kémiai szerkezetük alapján négy csoportba oszthatjuk őket (1. táblázat): izoflavonoidok, lignánok, kumesztánok, sztilbének [16].

A lignánok maguk nem rendelkeznek ösztrogénhatással, metabolitjaik azonban már igen. Széles körben megtalálhatók a növényvilágban, a növényeken belül több szervben is előfordulnak. A magvakban, mint például a lenmagban, szezámmagban vagy a búzában, nagy menynyiségben dúsulnak fel. Jelentős ösztrogénhatást kiváltó sztilbénszármazék a rezveratrol, ami például a szőlőben, vörösborban, földimogyoróban fordul elő. A kumesztánok a hüvelyesekben gyakori vegyületek, bioszintézisük szerint az izoflavonoidok származékai. Legnagyobb koncentrációban a lucernában és a réti herében találhatók meg [17]. A menopauza terápiája szempontjából legfontosabb hatóanyagok az izoflavonoidok.

\section{Fitoösztrogének szerkezet-hatás összefüggése}

A fitoösztrogének az endogén ösztrogénekkel mutatnak hasonlóságot szerkezetükben, méretükben és molekulatömegükben, illetve molekuláik át is fednek a $17 \beta$-ösztradiollal (1. ábra).

Ezek a vegyületek ugyanazokhoz a receptorokhoz képesek kötődni, mint az ösztrogén, azonban valamelyest kisebb receptoraffinitással, így hormonszerü hatásaik mérsékeltebbek. A kölcsönhatáshoz szükségesek bizonyos szerkezeti elemek, például a molekula két végén elhelyezkedő $\mathrm{OH}$-csoportok távolsága, az aromás gyưrü és a fenolos $\mathrm{OH}$-csoport jelenléte [17].

\section{Farmakokinetika, metabolizmus}

Az izoflavonoidok emberben történő felszívódásának vizsgálatakor azt tapasztalták, hogy a glikozidok nagy molekulatömegük és hidrofil jellegük miatt nagyon gyengén szívódnak fel. A bélrendszerben baktériumok hatására észterázok és/vagy $\beta$-glikozidáz enzimek aglikonná alakítják, amelyek gyorsabban és nagyobb mértékben szívódnak fel. Következésképp elmondható, hogy az aglikonoknak nagyobb a biohasznosíthatósága. Adszorpció után beépülnek a kilomikronokba. A kilomikronremnantok a májba kerülnek, ahol az izoflavonoidok metabolizálódnak, főleg glükuronizációval, kisebb hányadban szulfatálással. Metabolizmus után az epével ürülnek a bélbe, ahol a metabolitok részt vehetnek az enterohepaticus körforgalomban. A bélbaktériumok a glükuronsavat enzimjeikkel lehasítják, az izoflavonoidok újra felszívódnak a szisztémás keringésbe. Nagy részük széklettel, de 10-30\%-ban vizelettel is ürülnek [18, 19]. 


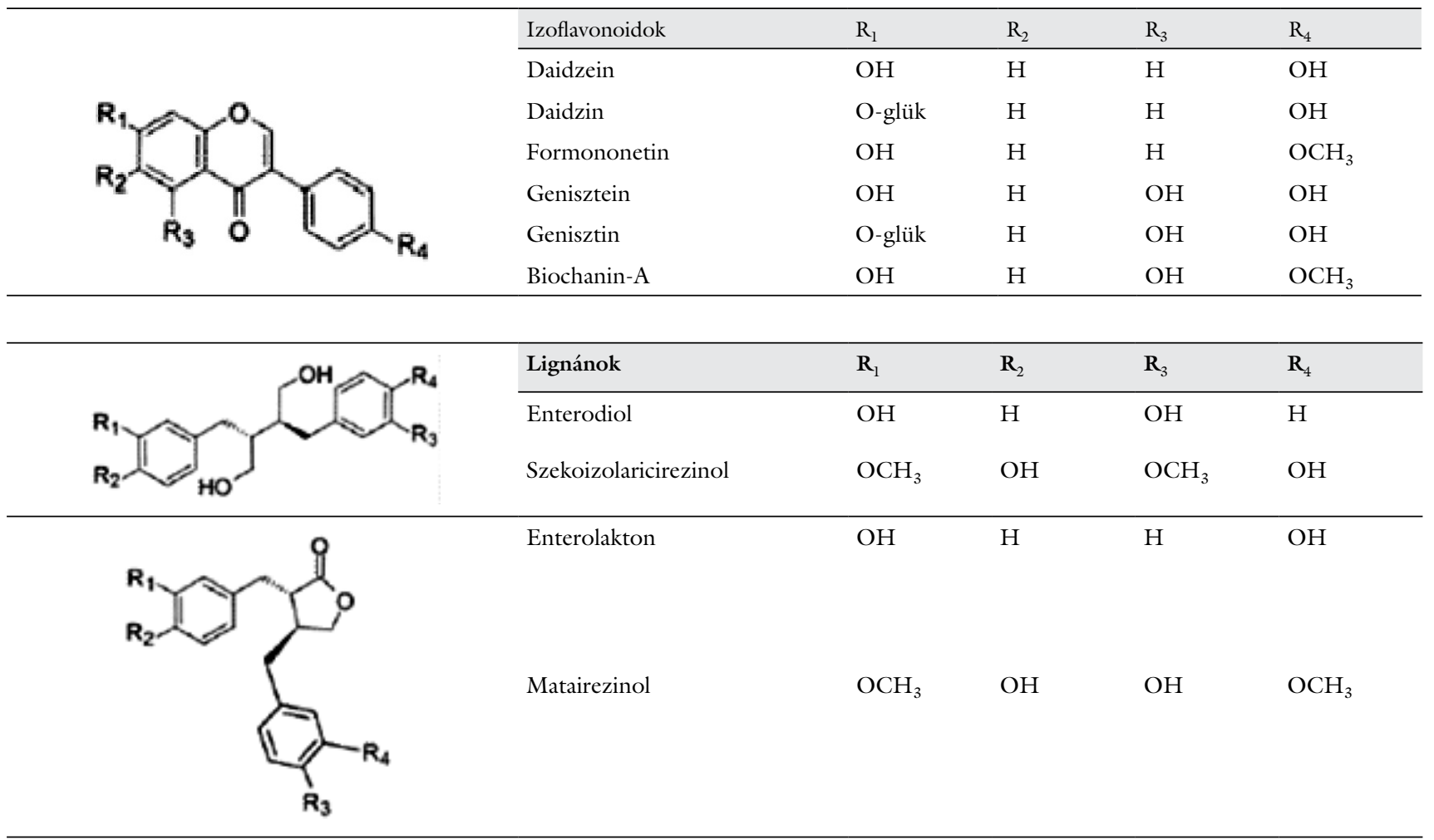

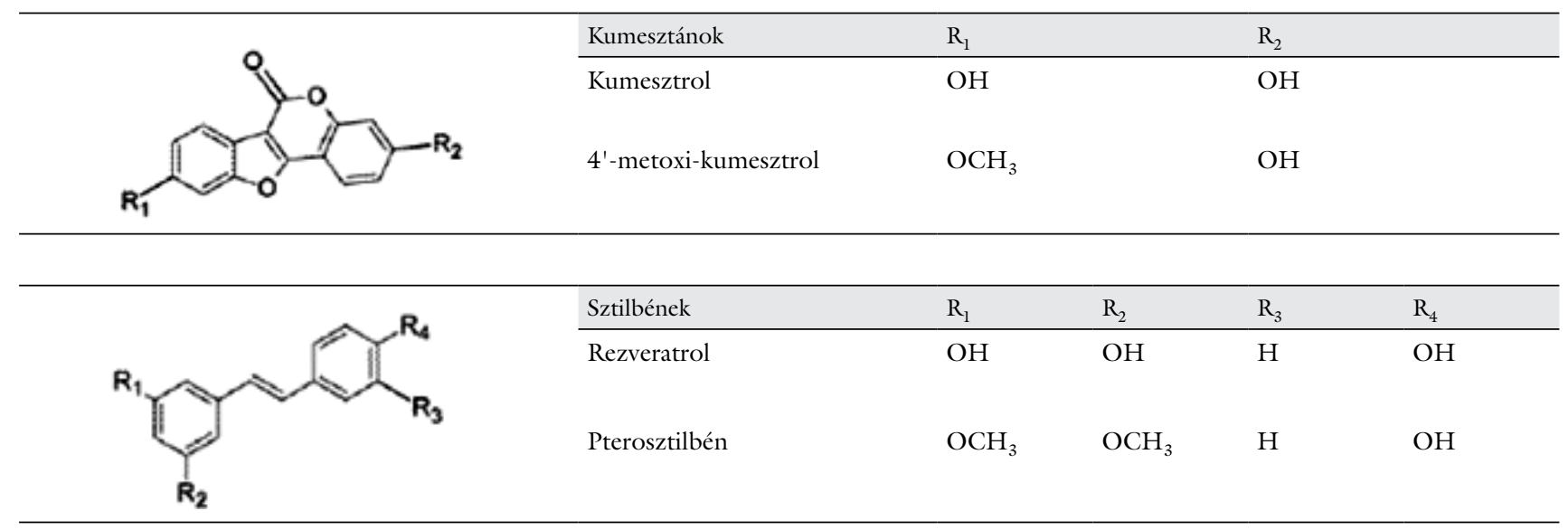<smiles>CC12CCC(c3ccc(O)cc3)C(c3ccc(O)cc3)C1c1ccc(O)cc1OCC2c1ccccc1</smiles>

1. ábra | Izoflavonoidok átfedése az ösztrogénszármazékokkal [19]
Az S-equol nem fordul elő a szója termésében, de az ember szervezetében mégis tud képződni bélbaktériumok által geniszteinből és daidzeinből. Antibiotikumokkal végzett kísérletek során bebizonyították, hogy több baktériumfaj (Eggerthella-, Lactobacillus-, Lactococcus-, Slackia-fajok) felelös a transzformációért (2. ábra). A baktériumpopuláció változása, az antibiotikumok és az étrendváltoztatás módosíthatja az egyén equoltermelő képességét. Mivel jelentős ösztrogénszerü hatásokat vált ki a szervezetben, ennek nagy jelentősége van. Nem minden ember szervezete képes viszont az equol szintézisére. Az ázsiai országokban a populáció $80 \%$-a, Európában és Észak-Amerikában csupán a lakosság negyede equoltermelő, tehát az egyének között jelentős különbség van a metabolizmusban [20]. 


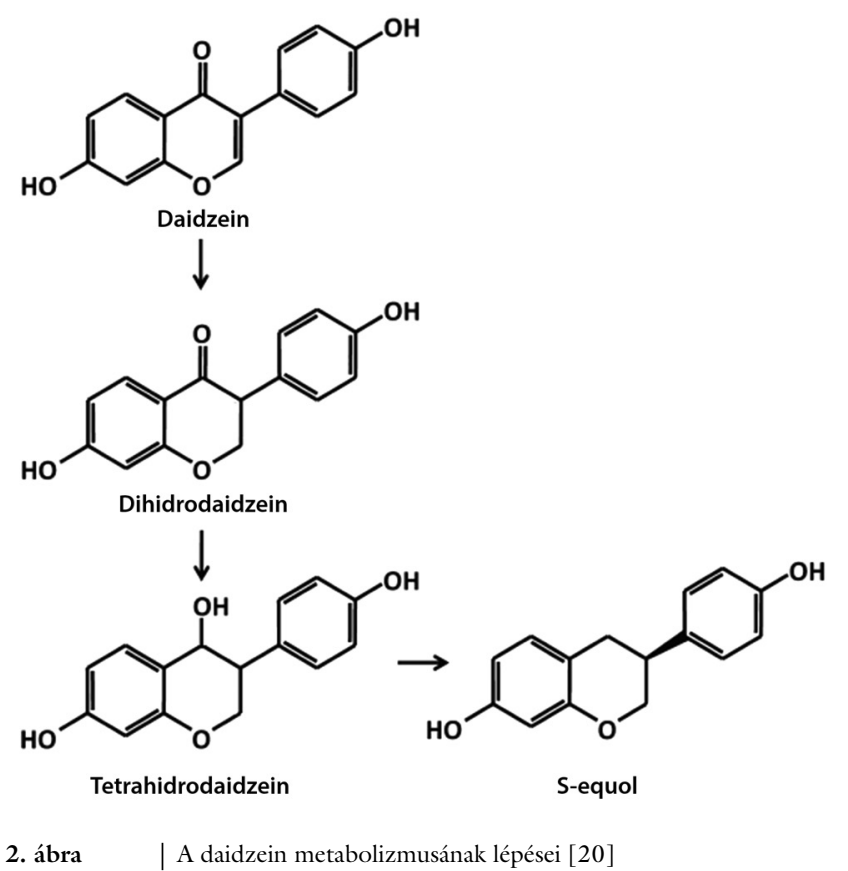

Egy embereken végzett tanulmányban az izolált izoflavonoidok (daidzein, genisztein és $\beta$-glikozid származékaik) farmakokinetikáját vizsgálták. Az eredmények szerint a vérben mérhető maximális koncentrációig eltelt idő glikozidált származékok esetében hosszabb, mint aglikonok esetében, a különbséget a cukorrész hidrolíziséhez szükséges idő okozza, ami elengedhetetlen a biohasznosuláshoz. A genisztein biohasznosíthatósága a daidzeinéhez képest nagyobbnak bizonyult, emellett a két izoflavonoidot egyforma dózisban adagolva megfigyelték, hogy a genisztein plazmakoncentrációja magasabb, mivel a daidzein nagyobb folyadéktérben oszlik meg [21].

$\mathrm{Az}$ ösztradiol mindkét receptorához nagy affinitással kötődik. A fitoösztrogének ezzel szemben szelektív ösztrogénreceptor-modulátor (SERM) molekulák, nagyobb affinitással kötődnek az ERß-hoz, mint az ER $\alpha$-hoz, egyes szervekben ösztrogénagonista hatás, más szervekben pedig antagonizáló hatás érvényesül. Izoflavonoidok glikozidjai (daidzin, glicitin, genisztin) nagyon gyengén kötődnek az ösztrogénreceptorok mindkét fajtájához. Az aglikonok (daidzein, genisztein, glicitein) közül a genisztein mutatja a legnagyobb affinitást, a 17ß-ösztradiolhoz hasonló erősségben. Az ösztrogénreceptor-függő transzkripciós expresszió vizsgálatakor megfigyelték, hogy a genisztein és a dihidrogenisztein az ösztrogénhez képest csökkent mértékben váltott ki indukciót. A vizsgált fitoösztrogének közül az equol a legerősebb induktor, különösen az ER $\alpha$ esetében. A daidzein nagyon gyenge hatással van az expresszióra, a glicitin és metabolitjai pedig a leggyengébb induktorok az öszszes többi vegyület közül [22].

A University of Southern California munkacsoportja fitoösztrogének in vivo és in vitro aktivitását vizsgálta ösztrogénreceptorokon, mind izolált formában, mind kombinációkban. Az ER $\alpha / \beta$ kötődési profil meghatározásához 17ß-ösztradiolt alkalmaztak pozitív kontrollként, a negatív kontroll pedig a progeszteron volt. Az analízis alapján a kötődési profil megváltozik, ha kombinációban alkalmazzák a geniszteint, daidzeint, equolt. A genisztein alakítja ki a legerősebb kötést a kétféle receptortípusra, az equol hasonló affinitással kötődik ER $\alpha$-ra, ER $\beta$-ra azonban kisebb affinitással. A daidzein a geniszteinhez képest gyengébb kölcsönhatásba lép mindkét receptorral. Genisztein és daidzein kombinálva 50\%kal kisebb affinitást eredményezett, mint amit a genisztein egyedül kiváltott, ez a kombináció a szelektivitásban viszont növekedést mutatott. Ha mindhárom vegyület szerepelt a keverékben, akkor érték el a legnagyobb szelektivitást az ER $\beta-n$, ami $+30 \%$ szelektivitásbeli növekedést takar. Emellett javította a hatásosság/biztonságosság arányt is a többi kombinációhoz vagy a vegyületek önmagában történő alkalmazásához képest [23].

Mivel a fitoösztrogének föleg az ERß-ra hatnak, ezért hatásaikat elsősorban a petefészekben, a cardiovascularis rendszerben és az agyban fejtik ki. Sejtszintü hatásukat azonban több tényező is befolyásolja, köztük a célszövet, a receptorok állapota, az endogén hormonok jelenléte vagy hiánya, illetve a fitoösztrogének bevitt mennyisége is. Cardiovascularis rendszerben endothelfüggő és -független vasodilatatióval, illetve érszúkítés gátlásával befolyásolják az értónust. Az izoflavonoidok a csontrendszerre is jótékony hatást fejtenek ki, hatásmechanizmusuk valószínúsíthetően az osteoclastok apoptózisának aktivációja és az ösztrogénreceptorok modulációjával kiváltott tirozinkináz-aktivitás gátlása [18].

\section{Fitoterápia}

Tekintettel az összefoglaló terjedelmi korlátaira, a Fabaceae családba tartozó Glycine max, a szója izoflavonoidjainak hatásaira koncentráltunk.

\section{Hatás a vazomotoros és pszichológiai tünetekre}

Egy randomizált, placebokontrollált, kettôs vak tanulmány során pre-, peri- és posztmenopauzában vagy mútét kiváltotta klimaxban lévő nőket három csoportba osztottak. Az első csoport $25 \mathrm{mg}$, a második csoport 12,5 mg dózisban kapott szója terméséből izolált izoflavonoid aglikonokat, az utolsó csoport pedig placebót szedett. Az aglikonok a következők voltak: genisztein $51,8 \%$, daidzein 43,3\%, glicitein 4,9\%. A kezelés nyolc hétig tartott, a negyedik és nyolcadik héten a Menopauza Skála, Athén Insomnia Skála, illetve a Kórházi Szorongás és Depresszió Skála eredményei alapján értékelték a nők klimaxos tüneteit. A vizsgálat eredményei szerint a placebo és a $12,5 \mathrm{mg}$ dózisban alkalmazott aglikonok nem befolyásolták a nők egészségi állapotát. 
Az izoflavonoidok 25 mg dózisban már szignifikánsan csökkentették a depressziós tüneteket és az alvászavart is, emellett a Menopauza Skála értékeiben is szignifikáns javulást regisztráltak [24].

\section{Hatás a csontanyagcserére}

Epidemiológiai vizsgálatok szerint az ázsiai nőknél az osteoporosis, csípőtörés incidenciája kisebb, mint az amerikai vagy európai nők esetében. Ennek a jelenségnek az okát nem lehet csupán genetikai különbséggel magyarázni, hiszen az Egyesült Államokba emigrált és az amerikai étkezési szokásokat átvevő mongoloid típusú nőknél nagyobb az osteoporosis kialakulásának rizikója, mint az ázsiai országokban élő társaiknak. A kutatók az ázsiai étrenddel, azon belül is a szójában gazdag ételek fogyasztásával magyarázzák a mortalitásban megjelenő különbségeket [25].

Egy 2017-ben publikált cikk arról számolt be, hogy a menopauzában lévő nők csontrendszerére kedvező hatással voltak a szója izoflavonoidjai. Randomizált, kettős vak vizsgálat során 200 nőt két csoportba osztottak, 100 nő naponta $15 \mathrm{~g}$ szójafehérjét fogyasztott, 100 nő pedig $15 \mathrm{~g}$ olyan szójafehérjét, ami $66 \mathrm{mg}$ izoflavonoidot is tartalmazott. Hat hónap után az izoflavonoidokat is fogyasztó egyéneknél a csontátépülés markereiben $(\beta-\mathrm{C}$ telopeptid, l-es típusú prokollagén-N-propeptid) szignifikáns változást figyeltek meg [26].

\section{Hatás a cardiovascularis rendszerre}

A fitoösztrogéneken kívül a szójafehérje is jótékony hatással van az emberi szervezetre. Regöly-Mérei és mtsai hypercholesterinaemiás idős nők esetében csökkent szérumkoleszterin-szintet figyeltek meg három hónapnyi napi 5 g mennyiségü szójabevitel után [27]. Ruscica és munkacsoportja randomizált, placebokontrollált tanulmányban vizsgálta a szója hatását a cardiovascularis rendszerre és a metabolikus szindrómára. A vizsgálatba 4575 év közötti önkénteseket vontak be, akiknek kritérium szerint a metabolikus szindróma öt jellegzetes jellemvonásából legalább hárommal kellett rendelkezniük. Az alanyok egyik fele szójadiétát folytatott, a másik fele kontrolldiétán volt, összesen 109 fó fejezte be a diéta valamelyik formáját. A szójadiétán lévők 30 g szójafehérjének megfelelő, kereskedelmi forgalomban kapható terméket fogyasztottak 12 héten át. A vizsgálat eredményei szerint jótékony hatással volt a szervezetükre; a tanulmányban részt vevők fele a metabolikus szindróma jellemzőiben szignifikáns változást tapasztalt a kontrollcsoporthoz képest. Csökkent a testsúly, a testtömegindex (mindkettő 1,5\%-kal), javulás történt a lipidprofilban, az összkoleszterinszint 4,85\%-kal, az LDL-koleszterin koncentrációja 5,25\%-kal csökkent. A kísérlet alapján a szójabevitel szignifikánsan csökkentette a cardiovascularis rizikót és a metabolikus szindróma tüneteit is kedvezően befolyásolta [28].

\section{Tumorellenes hatás}

Epidemiológiai vizsgálatok szerint az emlőrák gyakorisága az ázsiai országokban jelentősen kisebb, mint az Egyesült Államokban vagy Európában, ezt a jelenséget szintén a fokozott szójafogyasztással hozták összefüggésbe [29].

Vizsgálatok kimutatták, hogy a szója hatóanyagai rákellenes tulajdonsággal rendelkeznek. A kontrollálatlan angiogenezis kulcsfontosságú a tumorok terjedésében, méretük növekedésében. A genisztein több módon is tudja gátolni az angiogenezist, jelátviteli utak módosításával, génexpresszió befolyásolásával. 5-50 $\mu \mathrm{M}$ koncentrációban meggátolta a humán köldökvéna-endothelsejtek (HUVEC) növekedését, illetve szignifikáns mértékben VEGF-expresszió-gátló (vascularis endothelialis növekedési faktor), ami az angiogenezis egyik regulátora. A genisztein tehát a tumorsejtek és az endothelsejtek közötti VEGF-mediált szignálútvonal gátlásával fejtheti ki rákellenes hatását. Hatását a hypoxia indukálta faktor-1 (HIF-1) fehérje aktivációjának gátlásával is kifejtheti. Ezen az útvonalon is a VEGF-gén expresszióját gátolja. A geniszteinnel kezelt sejtekben egyéb, angiogenezisben szereplő fontos fehérjék is gátlódtak, például a vérlemezke-eredetû növekedési faktor (PDGF), az urokináz plazminogén aktivátor $(\mathrm{uPa})$. A mátrixmetalloproteáz-2 (MMP-2) gátlásával pedig az extracelluláris mátrix angiogenezisben való részvételét akadályozza meg. A HUVEC-sejtekben azoknak a géneknek az expressziója módosult, amelyek a proliferációban, adhézióban, apoptózisban és metabolizmusban játszanak meghatározó szerepet [30].

Az Amerikai Rákkutató Szövetség (AICR) nyilatkozata a szója fogyasztását embereken elvégzett vizsgálatok eredményeire hivatkozva emlőráktúlélők számára biztonságosnak nyilvánította [31].

\section{Kételyek és ellentmondások a menopauza fitoterápiájában}

A menopauza fitoterápiájának szempontjából a szakirodalomban számos ellentmondásos forrással találkozunk. Összefoglalónkban eddig olyan kísérletek és vizsgálatok szerepeltek, amelyek szerint a gyógynövények jótékony hatással vannak a szervezetre, azonban sok vizsgálat ezeket a hatásokat megcáfolta vagy a nem kedvező előny/ kockázati arány miatt a kivonatokat nem ajánlja a menopauzás tünetek csillapítására.

A Magyar Menopausa Társaság 2016. évi állásfoglalása szerint a gyógynövény-terápia több szempontból is aggályos. A fitoösztrogének hatékonysága elmarad a HPKétól, alkalmazásuk pedig gyógyszerkölcsönhatást okozhat. További gondot okoz, hogy a nem gyógyszertári forgalomban lévő fitoterapeutikumok nincsenek standardizálva, különböző növényi kivonatokat tartalmazhatnak más-más koncentrációban. Az izoflavonoidok jelenléte a termékekben nagymértékben függ a gyártástechnológiá- 
tól. E tényezők miatt nehéz feladat a dozírozás és a készítmények tudományos összehasonlítása is. Nem ajánlott betegeknek interneten keresztül beszerezhető „bioidentikus" ösztrogéneket (a szervezet által természetesen előállított hormonok kémiai megfelelői) fogyasztani, mivel ezek a készítmények klinikai vizsgálatokban nem lettek kipróbálva: ismeretlen a hatékonyságuk és biztonságosságuk is [32-34].

Emlőrákban a fitoösztrogének szerepe rendkívül öszszetett, a vizsgálatok eredményei pedig ellentmondásosak. Bizonyítékok találhatók mind pozitív, mind negatív hatásaikra.

In vitro egy táplálék-kiegészítőből izolált S-equol, a daidzein, a glicitein, a genisztein és a táplálék-kiegészítőben található izoflavonoidok keveréke egyaránt serkentette az MCF-7-E10 (humán emlőadenocarcinoma-sejtvonal) sejtek proliferációját. A kísérlet szerint a sejtproliferációhoz a $17 \beta$-ösztradiolhoz képest $10^{4}-10^{7}$-szeres koncentráció szükséges. In vivo azonban tumorbeültetett és petefészek-eltávolított egereknél az izoflavonoidokkal kezelt és a kontrollcsoport között nem volt különbség a rákos sejtek proliferációjában és a tumor méretében 500 ppm koncentrációban alkalmazva sem. Az izoflavonoidok eszerint a hormonfüggő rák progresszióját nem gyorsítják, biztonságosan alkalmazhatják akár rákos vagy rákot túlélő nők is. A kutatók nem zárják ki, hogy az emlőszövetben kisebb az izoflavonoidok koncentrációja, mint amilyen koncentrációban in vitro kísérleteket végeznek, emiatt nincs fokozott tumorkockázat in vivo [35].

Helferich és mtsai kísérlete szerint a genisztein dózistól függően a már kialakult ösztrogénfüggő emlődaganat növekedését elősegítheti. A tamoxifen az emlőrák gyógyszeres kezelésének egyik szere. A genisztein a vizsgálat szerint antagonizálhatja a tamoxifent, ezáltal csökkenti a rákterápia hatékonyságát, emiatt fogyasztása kontraindikált tamoxifennel kezelt emlőrákos nőknél. Bizonyos faktorok befolyásolhatják a fitoösztrogének hatását: felszívódás, metabolizmus, az egyed hormonális és egészségi állapota, ételek, gyógyszerek fogyasztása. Fontos tényező a fitoösztrogének összetétele és mennyisége, továbbá az is, hogy milyen életkorban fogyasztják ezeket [36].

Korábban említésre került, hogy a fitoösztrogének csökkentik a rák prevalenciáját, és az emlőrákot túlélő nők is szedhetik. Yang és mtsai a genisztein, daidzein, equol (mindegyik $750 \mathrm{mg} / \mathrm{ttkg}$ dózisban) és egy izoflavonoidokból álló keverék metasztázis kialakulását fokozó hatását vizsgálták in vivo. Utóbbi aglikon és konjugált formában geniszteint, valamint aglikon és konjugált formában daidzeint tartalmazott, amelynek dózisa 750 $\mathrm{mg} / \mathrm{ttkg}$ geniszteinre és $318 \mathrm{mg} / \mathrm{ttkg}$ daidzeinre volt standardizálva. Patkányok sípcsontjába 4Tl tumorsejteket injektáltak, amik végül mikrotumort alakítottak ki a csontban és áttétet képeztek a tüdőben. Az áttétképződés mértékét a tüdőn képződő tumoros göbök számával jellemezték. A kontrollcsoport egyedeinek tüdején átlagosan két göb volt megfigyelhető, míg a szója fitoösztrogénjeivel kezelt állatok esetében szignifikánsan nagyobb számban jelentek meg a göbök, átlagosan hat göb keletkezett. A fitoösztrogének az áttétképződést a sejtek proliferációjának fokozásával okozzák. A különböző izoflavonoidokkal kezelt csoportoknál a Ki-67 expressziója (ami a proliferáció mutatója) sokkal nagyobb arányú volt. Genisztein esetében 28\%, daidzein esetében 35,9\%, equolos csoportnál 28,6\%, több izoflavonoiddal együtt kezelt egyedeknél ez az érték pedig 34,3\% volt. A kísérlet tehát a fitoösztrogének metasztázisképzést fokozó hatását bizonyította, ennek alapján is felvetődik a gondolat, hogy rákban szenvedőknél kockázattal járhat fogyasztásuk [37].

Newton és mtsai vazomotoros tünetektől szenvedő nőkön végeztek randomizált, placebokontrollált vizsgálatot. A vizsgálat során a nóket öt csoportba osztották, az első csoport naponta 70\%-os etanollal extrahált $160 \mathrm{mg}$ dózisú triterpén-glikozid-tartalmú poloskavész-kivonatot, a második csoport kilenc gyógynövénnyel kombinált poloskavész-kivonatot szedett. (A fó hatóanyagok, a triterpén-glikozidok nem tartoznak a fitoösztrogének közé, mivel nem izoflavonoidvázas vegyületek, hatásaikat a centrális neurotranszmisszió befolyásával érik el. A Cimicifuga racemosa azonban formononetin izoflavont is tartalmaz.) A harmadik csoport tagjai a gyógynövény-kombináció mellett szójadiétát is tartottak, amely során naponta kétszer szójában dús táplálékot kellett fogyasztaniuk (körülbelül 12-20 g mennyiségű szójafehérjét). A negyedik csoport konjugált equin ösztrogént kapott $0,625 \mathrm{mg} / \mathrm{nap}$ dózisban. Az utolsó csoport volt a kontrollcsoport. A vizsgálat során azt tapasztalták, hogy nincs szignifikáns különbség a kontrollcsoport és a gyógynövényekkel kezelt nők vazomotoros tüneteinek intenzitásában a vizsgálat harmadik, hatodik és 12. hónapjában sem. Szójafogyasztás esetében a 12 . hónapban a placebóhoz képest még romlottak is a tünetek. A poloskavésszel kezelt nók éjszakai izzadása csupán a harmadik hónapban mutatott kedvező szignifikáns változást. Ekkor a nők naponta kisebb mértékben tapasztaltak éjszakai izzadást a placebocsoporthoz képest. A Wiklund Menopauza Skála tüneti értékeinek változásában nincs különbség a placebo- és a gyógynövénnyel kezelt csoportok között. A hormonpótlás hatékonyan csillapította a tüneteket, és a Wiklund Menopauza Skála értékei is csökkentek a placebo- és a gyógynövény-terápiával szemben is. A kísérlet szerint a gyógynövények hatékonysága messze elmarad a hormonterápiához képest, nem megfelelő alternatívák a menopauza tüneteinek csillapítására [38].

St. Germain és mtsai egy 24 hetes vizsgálat során azt tapasztalták, hogy sem a szójafehérje, sem az izoflavonoidok nem csökkentették a vazomotoros tüneteket. A randomizált, kettős vak vizsgálatban 69 nő vett részt. Az első csoport naponta $80,4 \mathrm{mg}$, a második csoport 4,4 mg szója aglikon izoflavonoidot kapott. A kontrollcsoport tejsavófehérjét fogyasztott. A tanulmány eredménye 
szerint nem volt szignifikáns változás a hőhullámok, éjszakai izzadások intenzitásában vagy gyakoriságában egyik csoport esetében sem. Egyéb tünetek (hangulatingadozás, hüvelyszárazság, libidócsökkenés) javulást mutattak mindhárom csoportnál, azonban szignifikáns különbség nem volt a placebocsoporthoz képest. A vizsgálat alapján tehát a szója nem bizonyult a placebónál hatékonyabbnak a menopauza tüneteinek enyhítésében [39].

Carmignani és mtsai randomizált, kettős vak, placebokontrollált kísérletük során vizsgálták napi 90 mg szója izoflavonoid hatását, vizsgálták a cardiovascularis biomarkerek koncentrációjára, majd ezeket az értékeket összehasonlították az alacsony dózisú HPK és placebo alkalmazásakor tapasztalt értékekkel. A HPK $1 \mathrm{mg}$ ösztradiolt foglalt magába, amit $0,5 \mathrm{mg}$ noretiszteronnal kombináltak. A 16 hetes vizsgálat során a hormonkezelés az összkoleszterinszintet 11,3\%-kal, az LDL-koleszterin koncentrációját 18,6\%-kal csökkentette. A szójakészítmény ezzel szemben csak enyhe mértékben csökkentette az LDL-koleszterin-koncentrációt (1,9\%) és az összkoleszterinszintet $(0,7 \%)$, emellett csak kismértékben növelte a HDL-koleszterin-koncentrációt (10,2\%). Mivel semelyik biomarkert nem befolyásolta szignifikánsan, ezzel a vizsgálattal cáfolták a szója jótékony hatását a cardiovascularis rendszerre és a rizikók csökkentésének jelentőségét [40].

Humán vizsgálatokban bizonyították, hogy a szója komponensei befolyásolják a tüszőérést. Ugyanis a napi $45 \mathrm{mg}$ izoflavonnal egyenértékű szójafehérje-bevitel egészséges nókben a follicularis fázis megnyúlásához vezetett (összehasonlításként: egy csésze szójatej körülbelül $35 \mathrm{mg}$ izoflavont tartalmaz) [41].

A szója 15 összetevőjéról bizonyították be eddig, hogy allergizálhatnak, ami atópiás ekcémaként és gyomorbántalmakban manifesztálódhat. Ilyen vegyületek például a $\beta$-konglicinin, a Bowman-Birk tripszin-kimotripszin inhibitor és a Kunitz tripszininhibitor. A lektinek (hemagglutininek) a sejtfelszíni szénhidrátokkal kölcsönhatásba lépve károsítják a bélmucosa sejtjeit és agglutinálják a vörösvértesteket [42].

\section{Következtetés}

Az 1950-es évek óta alkalmazott hormonpótló kezelés hatékonynak bizonyult a menopauza tüneteinek enyhítésében, amit számos vizsgálat is megerősített. A több éven át alkalmazott ösztrogénszubsztitúció azonban sok nő esetében trombózist, sőt rákos megbetegedést okozott. Később tudományos vizsgálatokkal igazolták, hogy a hormonpótló készítmények valóban nem veszélytelenek, mert alkalmazásuk cardiovascularis kockázattal jár, ezenfelül sejtproliferatív hatásuk következtében hormonfüggő rosszindulatú daganat, emlő- és méhrák kialakulását eredményezhetik. Ennek ismeretében a nók többsége nem kívánja igénybe venni a HPK-t, ezért menopauzás tüneteiket alternatív terápiákkal kezelik.
A szakemberek részéről viszont tartózkodás, bizalmatlanság nyilvánul meg a fitoterápiával szemben, mivel sok esetben az alkalmazott növények hatásmechanizmusa sem bizonyított. A kutatások eredményei ellentmondásosak a hatékonyság és a biztonságosság szempontjából. A fitoösztrogének sok kedvező hatása mellett beszámoltak rákos megbetegedések kialakulásának fokozott kockázatáról is.

Mivel a gyógynövénytartalmú készítmények gyakran étrend-kiegészítőként, illetve homeopátiás szerként is forgalomba kerülhetnek, fel kell hívni a figyelmet arra, hogy a gyógyszerekkel ellentétben ezeknek a termékeknek klinikai kipróbálása a gyártók és forgalmazók részéről nem kötelező, sőt e vizsgálatokat, ritka kivételtől eltekintve, nem is végzik el, vagy az alkalmanként előforduló hatástani vizsgálatok metodikája kívánalmakat hagy maga után.

Anyagi támogatás: A közlemény megírása anyagi támogatásban nem részesült.

Szerzôi munkamegosztás: R. J.: A szakirodalom kutatása, elemzése, az összefoglaló dolgozat megírása, szerkesztése. B. A.: A kutatás irányítása, szakértői feladat ellátása, stilisztikai munkák elvégzése. A cikk végleges változatát mindkét szerző elolvasta és jóváhagyta.

Érdekeltségek: A szerzőknek nincsenek érdekeltségeik.

\section{Irodalom}

[1] Utian WH. Menopause-related definitions. Int Congr Ser. 2004; 1266: 133-138.

[2] O’Neill S, Eden J. The pathophysiology of menopausal symp toms. Obstet Gynaecol Reprod Med. 2011; 22: 63-69.

[3] Georgakis MK, Thomopoulos TP, Diamantaras AA, et al. Association of age at menopause and duration of reproductive period with depression after menopause. JAMA Psychiatry 2016; 73 : 139-149.

[4] Mondul AM, Rodriguez C, Jacobs EJ, et al. Age at natural menopause and cause-specific mortality. Am J Epidemiol. 2005; 162 : 1089-1097.

[5] Snieder H, Macgregor AJ, Spector TD. Genes control the cessation of a woman's reproductive life: a twin study of hysterectomy and age at menopause. J Clin Endocrinol Metab. 1998; 83: 1875-1880.

[6] Steiner AZ, Baird DD, Kesner JS. Mother's menopausal age is associated with her daughter's early follicular phase urinary, follicle-stimulating hormone level. Menopause 2008; 15: 940-944.

[7] Hayatbakhsh MR, Clavarino A, Williams GM, et al. Cigarette smoking and age of menopause: a large prospective study. Maturitas 2012; 72: 346-352.

[8] Morris DH, Jones ME, Schoemaker MJ, et al. Body mass index, exercise, and other lifestyle factors in relation to age at natural menopause: Analyses from the breakthrough generations study. Am J Epidemiol. 2012; 175: 998-1005.

[9] Levin ER. Invited review: Cell localization, physiology, and nongenomic actions of estrogen receptors. J Appl Physiol. 2001; 91: 1860-1867.

[10] Smiley DA, Khalil RA. Estrogenic compounds, estrogen receptors and vascular cell signaling in the aging blood vessels. Curr Med Chem. 2009; 16: 1863-1887. 
[11] Pellegrini M, Pallottini V, Marìn R, et al. Role of the sex hormone estrogen in the prevention of lipid disorder. Curr Med Chem. 2014; 21: 2734-2742.

[12] Papp Z. Obstetrics and gynecology textbook. [A szülészetnőgyógyászat tankönyve.] Semmelweis Kiadó, Budapest, 2009; p. 92. [Hungarian]

[13] Nakamura T, Imai $Y$, Matsumoto T, et al. Estrogen prevents bone loss via estrogen receptor $\alpha$ and induction of Fas ligand in osteoclasts. Cell 2007; 130: 811-823.

[14] Stuenkel CA, Davis SR, Gompel A, et al. Treatment of symptoms of the menopause: An Endocrine Society Clinical Practice Guideline. J Clin Endocrinol Metab. 2015; 100: 3975-4011.

[15] Jyotsna VP. Postmenopausal hormonal therapy: Current status. Indian J Endocrinol Metab. 2013; 17(Suppl 1): S45-S49.

[16] Gencel VB, Benjamin MM, Bahou SN, et al. Vascular effects of phytoestrogens and alternative menopausal hormone therapy in cardiovascular disease. Mini Rev Med Chem. 2012; 12: 149174

[17] Michel T, Halabalaki M, Skaltsounis AL. New concepts, experimental approaches, and dereplication strategies for the discovery of novel phytoestrogens from natural sources. Planta Med. 2013 79: 514-532.

[18] Pilšáková L, Riečanský I, Jagla F. The physiological actions of isoflavone phytoestrogens. Physiol Res. 2010; 59: 651-664.

[19] Aguiar PM, Barbosa AP. Use of soy isoflavones on hormone replacement therapy during climacteric. Afr J Pharm Pharmacol. 2014; 8: 1071-1078.

[20] Jackson RL, Greiwe JS, Schwen RJ. Emerging evidence of the health benefits of $S$-equol, an estrogen receptor $\beta$ agonist. Nutr Rev. 2011; 69: 432-448.

[21] Setchell KD, Brown NM, Desai P, et al. Bioavailability of pure isoflavones in healthy humans and analysis of commercial soy isoflavone supplements. J Nutr. 2001; 131(4 Suppl): 1362S-1375S

[22] Morito K, Hirose T, Kinjo J, et al. Interaction of phytoestrogens with estrogen receptors alpha and beta. Biol Pharm Bull. 2001 24: 351-356

[23] Zhao L, Mao Z, Brinton RD. A select combination of clinically relevant phytoestrogens enhances estrogen receptor $\beta$-binding selectivity and neuroprotective activities in vitro and in vivo. Endocrinology 2009; 150: 770-783.

[24] Hirose A, Terauchi M, Akiyoshi M, et al. Low-dose isoflavone aglycone alleviates psychological symptoms of menopause in Japanese women: a randomized, double-blind, placebo-controlled study. Arch Gynecol Obstet. 2016; 293: 609-615.

[25] Zheng X, Lee SK, Chun OK. Soy isoflavones and osteoporotic bone loss: A review with an emphasis on modulation of bone remodeling. J Med Food 2016; 19: 1-14.

[26] Sathyapalan T, Aye M, Rigby AS, et al. Soy reduces bone turnover markers in women during early menopause: A randomized controlled trial. J Bone Miner Res. 2017; 32: 157-164.

[27] Regöly-Mérei A, Biró G, Lászlófi M, et al. The effect of soybean protein on lipids and trace elements in elderly hospitalized women. [Szójafehérje hatása hospitalizált idős nő́k lipid és mikroelem statusára.] Orv Hetil. 1991; 132: 1523-1526. [Hungarian]

[28] Ruscica M, Pavanello C, Morlotti B, et al. Soya-enriched mixed diet significantly improves cardiovascular and metabolic risk factors: A randomized controlled trial. Atherosclerosis 2016; 252 e210.
[29] Xie Q, Chen ML, Qin Y, et al. Isoflavone consumption and risk of breast cancer: a dose-response meta-analysis of observational studies. Asia Pac J Clin Nutr. 2013; 22: 118-127.

[30] Varinska L, Gal P, Mojzisova G, et al. Soy and breast cancer: focus on angiogenesis. Int J Mol Sci. 2015; 16: 11728-11749.

[31] American Institute for Cancer Research (AICR). Soy is safe for breast cancer survivors. Available from: http://www.aicr.org/ cancer-research-update /2012/november_21_2012/cru-soysafe.html?_ga $=1.145285757 .872698069 .1485088839$ [accessed: April 15, 2017].

[32] Health preservation and disease prevention for women during menopause. Recommendations for menopausal hormone therapy. Opinion of the Hungarian Menopause Society in August 2016. [A nők egészségének megőrzése és betegségeik megelőzése a változókorban. Ajánlások a menopauzális hormonterápiával kapcsolatban. A Magyar Menopausa Társaság 2016. augusztusi állásfoglalása.] Available from: http://www.mmt.hu/upload/ menopausa/document/mmt_allasfoglalasa_2016_augusztus. pdf?web_id=[accessed: April 15, 2017]. [Hungarian]

[33] Rigalli JP, Tocchetti GN, Arana MR, et al. The phytoestrogen genistein enhances multidrug resistance in breast cancer cell lines by translational regulation of $\mathrm{ABC}$ transporters. Cancer Lett. 2016; 376: 165-172.

[34] Szendrei K, Csupor D. Soy - a major source of food and medicine. [Szója - egy jelentős élelmiszer- és gyógyszerforrás.] Gyógyszerészet 2009; 53: 87-92. [Hungarian]

[35] Onoda A, Ueno T, Uchiyama S, et al. Effects of S-equol and natural S-equol supplement (SE5-OH) on the growth of MCF-7 in vitro and as tumors implanted into ovariectomized athymic mice. Food Chem Toxicol. 2011; 49: 2279-2284.

[36] Helferich WG, Andrade JE, Hoagland MS. Phytoestrogens and breast cancer: a complex story. Inflammopharmacology 2008; 16: 219-226.

[37] Yang X, Belosay A, Hartman JA, et al. Dietary soy isoflavones increase metastasis to lungs in an experimental model of breast cancer with bone micro-tumors. Clin Exp Metastasis 2015; 32: 323-333.

[38] Newton KM, Reed SD, LaCroix AZ, et al. Treatment of vasomotor symptoms of menopause with black cohosh, multibotanicals, soy, hormone therapy, or placebo: a randomized trial. Ann Intern Med. 2006; 145: 869-879.

[39] St. Germain A, Peterson CT, Robinson JG, et al. Isoflavone-rich or isoflavone-poor soy protein does not reduce menopausal symptoms during 24 weeks of treatment. Menopause 2001; 8: $17-26$.

[40] Carmignani LO, Pedro AO, da Costa-Paiva LH, et al. The effect of soy dietary supplement and low dose of hormone therapy on main cardiovascular health biomarkers: a randomized controlled trial. Rev Bras Ginecol Obstet. 2014; 36: 251-258.

[41] Csupor-Löffler B, Csupor D. The two-faced soy. [A kétarcú szója.] Családorvosi Fórum 2004; 9: 82-84. [Hungarian]

[42] Medic J, Atkinson C, Hurburgh CR. Current knowledge in soybean composition. J Am Oil Chem Soc. 2014; 91: 363-384.

(Blázovics Anna dr., Budapest, Üllői út 26., 1085 e-mail: blazovics.anna@pharma.semmelweis-univ.hu) 